UDC 7.011

\title{
Museum Director: Job, Profession, or...? A Hundred-Year Long Experience of Directorship at the Peterhof State Museum-Reserve
}

\author{
E. Ya. Kalnitskaya
}

State Museum Reserve "Peterhof",

2, Razvodnaya ul., Peterhof, St. Petersburg, 198516, Russian Federation

For citation: Kalnitskaya, Elena. "Museum Director: Job, Profession, or...? A Hundred-Year Long Experience of Directorship at the Peterhof State Museum-Reserve". Vestnik of Saint Petersburg University. Arts 10, no. 2 (2020): 340-365. https://doi.org/10.21638/spbu15.2020.209

When studying the history of museum work, modern cultural scholars have not paid enough attention to the issues of museum management, which are of great importance for every museum. The museum consisting of the palaces and parks of Peterhof, established after the nationalization of the imperial residence in 1918, were initially headed by a curator and later by a director. The director determined museum policy, organized scientific, conservation, financial and economic work, and maintained contacts with government officials. In the early stages of the museum's development, the director's responsibilities included organization of educational work, inventory of palace collections, and preservation of architectural monuments. Later on, the area of responsibilities expanded and changed to keep up with the historical process. Workers of culture and people with a more democratic background held the director's position. Numerous Party bureaucrats later gained the position, and during the last stage historians with a special education served as directors. Having gone through the transformation of palaces and museums into "museums of noble life", the conversion of historical landscapes into parks of "culture and recreation", through the tragedy of political repressions and wartime evacuation, through the difficulties of the post-war revival of the complex and many other things, the directors of the Peterhof museum created an amazing historical and cultural phenomenon known all over the world today.

Keywords: Peterhof, museum-palace, historical and cultural phenomenon, director of the museum, museum management, restoration, museology, cultural studies.

(c) Санкт-Петербургский государственный университет, 2020 
We do not choose time,

We live in it and die...

The range of official duties stipulated in the "Museum management" section of the current Charter of the Peterhof museum is remarkable as it encompasses a great number of issues, all of which have to be dealt with by the museum director [I, p. 16]. The functions for which the director is personally responsible for are numerous and varied. This has existed throughout the one-hundred-year long history of the Peterhof State Museum-Reserve. The directors have determined the policy of the museum, combined economic and administrative methods of management, assumed responsibility for the consequences of their decisions, preserved and effectively used the property of the museum and solved numerous other problems.

In the last decades, museums in Russia have been undergoing a period of change. The economic policy of the state in regards to culture has transformed. An increase in attention to museums' activities has been observed among a significant portion of the population. In the time of globalization, while the museum is conservation in nature, its director should change in accordance with the transformations of modern life.

Since the very beginning of Soviet museum history, museums have performed three primary functions - to preserve, to study and to popularize museum collections, which determined their main activities: preservation, research and education. They have always existed alongside financial and economic activities, process of preservation, operation and maintenance, construction, legal operations and others.

The history of museums has been actively studied of late. Biographies of museum employees or so called "museum workers" have seldom aroused the interest of researchers. Museum directors hardly ever wrote memoirs and rarely kept diaries due to lack of time. The only exception is wartime memoirs devoted to the history of evacuating museum collections including that of Peterhof. The authors of such memoirs realized the need for describing and remembering the events and facts they had witnessed $[1 ; 2 ; 3$, p. 345-6].

The situation has changed in the last few years: The State Hermitage Museum started to publish collections of memoirs in the Curator series which includes letters, documents, recollections of the life and work of those who worked at the country's main museum. Gradually, other museums also began to collect and publish materials on the subject: in 2010, the Peterhof State Museum-Reserve embarked upon the research project "Problems of Cultural Heritage Preservation: $21^{\text {st }}$ Century" dedicated to the everyday work of museums and lives of their employees. As part of the project, several works devoted to Peterhof directors, employed at different times, have been published in art history publications [4; 5, p. 83-7; 6, p. 16-20; 7, p. 7-20; 8, p. 12-46; 9, p. 188-91; 10; 11]. In 2018, historian Alexander Belousov published a first-hand account of gathering collections narrated to him by the long-standing director V. V.Znamenov. The first attempt to analyze the work of directors of suburban museum-palaces [12, p. 20-37] and Peterhof directors [13, p. 67-80] was made in connection with the centennial anniversary marking the conversion of imperial residences into state museums. The present paper continues to reflect on the careers of the fourteen directors of Peterhof museums and parks and considers their work in the cultural context against the background of historical events and changes in the cultural policy of the state over the $20^{\text {th }}$ century. 
The first directors, initially called curators, happened to work at a critical time in the history of Russia. Four administrators appointed by the new authorities in Peterhof, Tsarskoye Selo, Pavlovsk and Gatchina belonged to the intelligentsia. Prior to the October revolution, directors were humanities scholars, studied architectural monuments and museum collections, but no matter how well educated they were, they had no prior experience in the specific area of museum work. Nevertheless, they were ready to put the principles of cultural heritage preservation into practice and responded to the authority's request. They did their best to find common ground with the regime and be of use. "These people demonstrated desire and were able to assume responsibility for overseeing the safeguarding of the palaces transformed into museums. Their names will be remembered in Russian museum history since all of them (and almost to the same degree) did all they could", Alexander Benois wrote [14, p. 73].

The summer residence of Peter the Great was in the possession of the Romanov family from generation to generation. Until 1917, the whole complex was managed by the Peterhof department of the Ministry for the Imperial Court. Its further development was determined by nationalization; the decree of the Provisional government of May 27, 1917 established historical and art committees in Peterhof and other suburbs, whose task was to take charge of the palace, catalogue and protect its property which from that time on was to become a museum.

The first director of Peterhof museums was Fyodor Berenstam (1862-1937), a painter, an architect and a graduate of the Imperial Academy of Fine Arts. He was engaged in publishing and contributed to such magazines as The Open Letter, Niva, World Illustration, Art Review. He was one of the organizers of international exhibitions in Munich, Rome and Venice. He accepted the February revolution as a "conscious citizen" and started working at Tsarskoye Selo. Shortly after, Benois who worked with him on the History of Russian Art recommended Berenstam for the post at Peterhof. Upon becoming director, Berenstam became in charge of 150 employees and in November of 2018, he was appointed director of the palaces in Oranienbaum.

Berenstam's ultimate and most important task was the organization of educational work: the victorious class wished to see the former imperial palaces in order to understand the life of the fallen class. On June 2, 1918, the rooms of the Grand Palace were opened for the first 400 visitors. The tours were guided by F. G. Berenstam, M. M. Izmailov and A. A. Polovtsev. From that time on, the flow of curious citizens constantly increased, which prompted the director to write special "Rules for the visitors at the Peterhof museum-palaces". In accordance with these rules, adult visitors were issued free tickets, while children were not admitted. Organized tours were changed in accordance with the behavior of a new type of visitors, which required specific skills. In his diary, Benois made an entry dated 19 July, 1923, "In the morning, Berenstam dropped by. He told me about the 'wonders' at Peterhof caused by the amount of tourists arriving by steamboats. The other day, the curators were engaged in a brawl on the Merchants Staircase and had to give a few good punches to restrain a mob of fifteen hundred who demanded that they should be admitted to the palace all at once. This scuffle saved the situation; otherwise, they would have ravaged everything. In the parks, there are no guards, and these people tear out bushes, break benches, etc. and climb the fountains and statues" [15, p.585].

In January 1918, the Central Art Board discussed the future of suburban palaces: despite the obvious interest of the masses in the imperial court life, the new government 
did not care about such things as to who personally owned the Peterhof palaces or what the palaces looked like. Visitors soon began to get quite a controversial impression of the palaces which had lost their history, many of them becoming "museums of life of the nobility". Step by step, each palace turned into a "house without a master".

With the New Economic Policy underway, the number of museum-palaces rapidly decreased in numbers, with historical buildings being taken over by various offices. The art objects of interior design were sorted out, rearranged and sent to urban museums; they were prepared for auctions that started in the mid-1920s. This all disappointed Berenstam, "The palaces and pavilions of Peterhof located amid magnificent parks and gardens adorned with their scenic ponds, fountains, statues and the like must be kept as intact as possible and these palaces and pavilions must be used as historical and art museums with their collections of pure art side by side with the examples of applied art. Our duty is to show our people these telling pages, these vivid illustrations of the past; it is necessary to do this in such a way as to guarantee their preservation for generations to come..." [16, p.23].

In autumn of 1918, the system of managing suburban palaces underwent a serious transformation. The decree of the Property department at the Commissariat for Education issued on November 14 established a new order: each museum received as its director "a special Commissar heading an administrative and property council with a curator or its deputy, a person responsible for the property and utilities of palaces and a representative of employees". Besides the Commissar, the decree mentioned "a special curator to supervise art and art related studies at the museum; to protect and study" the complex [II, p. 15]. This was a well thought-out and well-organized dual power: commissars were made responsible for administrative issues without any understanding of the specifics of museum work and without realizing the value of the art treasures entrusted to them. The curators were not involved in the management, nor were they invited to discuss financial or everyday issues. Thus, they were distanced from some important aspects of museum life.

Anatoly Lunacharsky, the People's Commissar for Education, in his constant search for compromises, tried to convince museum authorities that a difference in political views must not hinder mutual work. "Let us join hands and save the cultural heritage of our dear Fatherland, overlooking such things as what we are - optimists or pessimists, aristocrats or democrats. With a common goal we will find common ground", that was his message $[17$, p. 492]. Museum policy of the first post-revolutionary years was inevitably approaching its downfall; nevertheless, the first steps for establishing the profession of a museum director were taken.

Constant standoffs between the Commissar and the curator in 1922 resulted in a reform of the management of palaces and parks at Peterhof. At last, employees were engaged in real museum work of making an inventory of the collection which included making lists of the objects of historical, artistic and cultural value and, on the other hand, to sort out and to catalogue the items for household use. This work became the beginning of the museum cataloguing system. Simultaneously, appropriate conditions were established for the display of the museum's collections and their storage. The absence of qualified workers resulted in the lack of any signs of a scientific system at Peterhof in the first post-revolutionary years. The ideologists of a new cultural policy did not require from Berenstam neither a program of museum development nor methodology for organizing its collection as well as an exhibition program and methodology for scholarly and educational work. 
Being a professional with a serious scholarly background, he probably did not find administrative work interesting, so he did not plan to devote his future life to museum work. In his letters dating back to his time at Peterhof, the director constantly complained about a low salary, scanty living conditions and an absence of specialists; he was enraged by the constant demands of Party bureaucrats to accommodate their families in Peterhof palaces for the summer. His low spirits affected the state of work at the museum. His colleague from Tsarskoye Selo, Lukomsky, wrote, "Things were bad at Peterhof. A very unfit former member of my board Berenstam ended up there (a combination of bad contact with 'new' demanding work under new conditions). After I managed to get rid of him at Tsarskoye Selo (he absolutely disrupted the 'tone' of work of the Central Art Board, doing nothing), he 'settled' in Peterhof, but unfortunately things did not go well there either..." [18, p. 10].

During the five years that Berenstam was director, the museum was incredibly successful: the Grand Palace was open for visitors year round, new summer palaces were opened in the Lower park and in Alexandria - "Monplaisir", "Marli", "Hermitage", "Cottage", "Farm" and Lower Palaces ("Lower Cottage"), the pavilions on Tsaritsin and Olgin islands. In 1918-1922, the catalogues of paintings, sculpture and architectural archive were finished; the work on cataloguing engravings, lithographs, porcelain, furniture and the collection of books from the Cottage and the Grand Palace was continued.

All of these achievements taken together give credit to the significant role of Berenstam in the history of Peterhof museums: the first director was the one who turned the imperial palace into a public museum. On March 5, 1924, an order by the Leningrad branch of Central Department for Science ordained Berenstam's transfer to the Public library, where he as a "researcher" continued to work in different professional unions and associations. This decision was dictated by the time: with the first stage of the museum's establishment having been completed, his post was to be taken over by people possessing strong Party skills.

The next stage saw an intellectual being replaced by someone with a more democratic background - Nikolai Arkhipov. He was appointed an aide to the curator in the Office of museum-palaces at Peterhof on the 1st of August 1924. Arkhipov (1887-1967), the son of a peasant woman and a worker who had moved to Petrograd, finished the well-known Vvedensky school in the Petrograd district; he was a student at the department of history and philology of Saint-Petersburg university and later joined the circle of Petersburg intellectuals. He came to be fond of theater, frequented some artistic cafes and, having a knack for public speaking, considered a career as an actor.

After university, the young historian was sent to teach at a public secondary school in the town of Vytegra in the Olonets region. During his stay there, he set up a local newspaper, became its chief editor, joined the Bolshevik party and worked as head of the department for registration and protection of old monuments. At that time, he befriended the poet Nikolai Kliuev native to this place, and their friendship was to last for many years. In later years, Arkhipov tried to shield his friend from the assaults of the authorities and critics without fear of risking himself. He started copying his poems and prosaic works, his stories and dreams, which was a very special literary genre. Kliuev bequeathed all of his works to Arkhipov, and thanks to him they survive to this day.

Upon arriving in Petrograd, Arkhipov was a school principal for teenagers from working families in the Narvsky district of the city. Shortly after that, he began his spectacular and dramatic career in museum work. He quickly became acquainted with the spe- 
cifics of his property at Peterhof and was appointed a curator, and later its director. Under Arkhipov's direction, Peterhof began to turn into one of the most favored and frequented museums of Leningrad. As a director, he made great efforts to change the perception of palaces and parks; his dream was to turn the natural curiosity of the visitors in the life of monarchs into an interest in Russian history.

Having started the transformation of the Romanovs' palaces into museums (he himself called this process "museum making"), Arkhipov wanted to propose new scientifically grounded concepts. Together with the young workers of the museum, he planned to transform this not-so-long-ago palatial complex, once inhabited by people, into an exhibition complex where the principles of museum making were to be aligned with the new ideology of culture.

Gradually, the number of directorial problems changed and increased - Arkhipov combined scholarly, cultural, educational, financial and everyday questions with problems associated with organizing exhibitions. He began a major renovation and restoration of the fountains and park buildings as the last large restoration was conducted under Alexander II. Restoration required historical research, the study of documents and technical drawings. With no specialists present, Arkhipov began his own study of the complex water supply system.

In autumn of 1924, museum workers had to deal with the consequences of a serious flood: water flooded the strip of land near the Gulf, filling the fountains with sand and silt. Many trees in the parks were toppled by the windstorm. The Lower Park and its palaces Monplaisir, Marli, Hermitage and the Lower Cottage in Alexandria were greatly damaged.

The parks required the director's special attention. Early in the $20^{\text {th }}$ century, the Upper Park lost its historical image due to the trees planted in the parterres and because the trees in the alleys were no longer kept trimmed. Arkhipov embarked upon a new task of laying out open lawns with bordering flower beds, mending fences, pylons, pergolas with trellises and berceaus. Park sculptures were placed along the alleys in accordance with iconographic and archival documents, which rendered the monument of landscape gardening its original look.

By the summer of 1927, "surprise" fountains were repaired: they had been out of use for thirteen years, among them the "Oak" fountain, "Little firs" and benches-fountains, as well as "The Sun" fountain which had been in disrepair for about 50 years. By the early 1930's, the cascades "The Golden Hill", "The Chessboard Hill", "Roman" fountains and "Adam" and "Eve" underwent major repairs. Serious work was done on the "Grand Cascade" and on "The Samson Canal".

Until the early 1930's, there were debates about the changes to the historical image of palaces, the point of these debates being preservation of their artistic and household décor in the collection, which belonged to their former owners, and principles of the collection display in the palatial interiors. The debates were centered on the choice of a particular historical period which would determine the specifics of restoration work. Soon a more precise and more grounded position of the specialists was adopted, which stated that suburban palaces should be viewed as monuments of a "year-long type". Since the August owners received them from their predecessors, rebuilt and passed them on to their successors, the principle of keeping intact all consecutive changes connected with the actual history of each monument was not aimed at a particular time period or style of a particular age. 
However, those palaces that had departed from their past and were turned into "museums of life of the nobility", very soon became museums "for a single visit", and the number of curious tourists rapidly declined. These exhibitions of everyday life were deemed to not correspond to Marxist theory, and authorities started to close museum-palaces. The process of "museum-making" at Peterhof was terminated: the authorities decided that palaces should become health and holiday centers, while parks should become parks of culture and recreation. This took place when the work on the museum complex was almost completed and there were hopes for a brighter future: in the late 1920's, in addition to the palaces opened in the initial post-revolutionary years new ones were added - the Cottage, the Lower Cottage, Catherine's Palace and Olga's part of the Grand Palace. The director of the palace was also in charge of the English Palace and park, the Belvedere, the pavilions of the Meadow Park, and the whole complex of palaces and parks at Oranienbaum.

The team of workers gathered by Arkhipov included, apart from experienced professionals and authors, M. M. Izmailov, A.S. Dakhnovich, N.P. Udalenkov and some young colleagues - S. S. Geichenko, A. V. Shamansky and K. A. Bolsheva. Together with archive workers from Leningrad, they organized exhibitions which recounted the history of the museums such as "Autocracy and Church" (1933), "War and Machinery" (1934), "Imperial Court and its Budget in the $18^{\text {th }}$ Century" (1934), "Imperialist War and the Fall of Tsarism" (1935) and others.

The achievements of this team, however, did not stop cultural bureaucrats in Leningrad from renting out palaces and their premises on a broader scale, though Arkhipov considered this practice unacceptable. "Some workers in the position of authority are far from understanding the peculiarities of museum work", he wrote, "they are apt to believe that the palaces of the last of the Romanovs are nothing out of the ordinary, that they do not have any artistic value, and that they should be closed and used in a more practical manner - as living quarters, as premises for holiday camps and centers" [19, p. 135]. The Grand Palace became a venue for mass events, which damaged its decor: in 1934 it was used for the famous reception of the Cheluskin heroes [20, p.70-1].

However, the director's opposition to the new directives of Party and Soviet leaders had no result, so Arkhipov and his colleagues came to the conclusion that the only compromise between the museum and the authorities could be on presenting the palaces from the standpoint of revolutionary ideology. They believe that this this new concept might allow them to protect historical complexes. With the director's support, young workers of the museum Geichenko and Shemansky came up with the idea of "supplementary" or thematic exhibitions. The idea behind them was to include in the palace interior significant additional texts and illustrations, such as captions, annotations, leaflets, diagrams and photos [16, p. 77-8].

Soon this exhibition method spread elsewhere: new concepts became a means of educational work with the masses, while the rooms of the Grand Palace retained their historical appearance. Thematic exhibitions were organized in keeping with the specific use of the rooms and their interior décor: in the Dance hall there was an exhibition "Entertainments at Court", in the Chesme Hall - "Foreign policy as it is was reflected in life in the court and in construction work", in the Throne Hall - "The retinue and entourage", in the White dining room - "Formal dinner as a showing off" [21, p. 31]. In the harshest historical situation, the method contrived at Peterhof played a positive role mitigating the 
friction between the museum and the authorities, and at the same time, the décor of the palace was partly preserved.

The director, however, did not want to stop here. He was concerned with damage done to the overall historical sight of the residence and the transformation of architectural monuments into "clubs for political education" - specific centers of Socialist propaganda. "I was not an adherent of conservatism in museum work, - he wrote later, - but I raised my voice against the mutilation and distortion of the historical and artistic image of Peterhof by inserting into its fountain parks pleasure pavilions, attractions, playgrounds and other amusements, which are necessary in the new parks but which inevitably become an eye-sore in the old parks of the $18^{\text {th }}$ century" [16, p.77-8].

Arkhipov expressed his concern over the plans to turn landscape parks into recreation areas for workers, "We are against lectures or political quizzes organized in every corner of the park, we are against posters or political slogans hanging on every tenth tree, we are against amusements that suppress visitors and make holes in their pockets" [19, p. 136].

In December 1930, Arkhipov participated in the First All-Russia Museum Congress in Moscow whose slogan was "Museums and their contribution to Socialist construction and cultural revolution". The new tasks confronting museums were expressed here in the following way - "Museum collections must become not only vivid and material illustrations of the most important concepts of the founders of the revolution and principal Party directives, but also a tool for mobilizing broad masses of people for their active participation in Socialist construction" [22, p. 16]. The officials proposed to get rid of the term "museum" as such, to display part of the collections on the streets, to shut down museum departments engaged in research and exhibition work, which still employed pre-revolutionary specialists.

In July 1933, an unexpected high-ranking visitor visited Peterhof - Stalin, the General Secretary of the Bolshevik Party, who came to Leningrad following his inspection trip at the construction site of the Belomorsko-Baltiisky canal. Stalin came to the "fountain residence" together with Klement Voroshilov. Sergei Kirov, the first secretary of Leningrad branch of the Communist party, decided to show them around the residence of Peter the Great, and Arkhipov, who was accompanying the delegation, got a chance to express before "the leader and teacher" his ideas about the future of Peterhof. He decided to ask Stalin a vital question about the need for preserving and displaying imperial property and received a positive answer.

At that time, the attendance of parks and palaces at Peterhof was high, with 1,5 million visitors in the summer of 1933. The museum, which was considered financially profitable, received serious dividends from its activities, but major repairs and restorations required extra financing from the state. Arkhipov failed to receive increased money from the budget, while minor repairs could not solve the problem of museum maintenance and preservation. The director's principal concern was the condition of the fountains. In 1935, he expressed his alarm noting "there is not a single fountain at Peterhof which is in full working order", while "the water has a yellowish dirty color and smells stench" [III, p. 13-4].

The authorities' demands to lease the premises of the palace did not stop. By the beginning of 1937, the number of museum buildings decreased from 36 to 11. Peterhof lost 
much of its territory in Alexandria Park which was turned into a large beach for locals ${ }^{1}$, while many palaces (the Farm, the Lower Cottage) became holiday homes. The Belvedere Palace in the Meadow Park was conceded to a health center of the "Krasny Putilovets" plant. The English Palace, the Private Cottage, Gothic, Chevalier and Maids-of-Honor Houses were also rented out. The director went on with his constructive criticism, "Some officials having a very remote idea of the peculiarities of museum work think that the palaces of the last family of the Romanovs are run-of-the-mill and do not have any cultural value, so they should be closed and used more pragmatically, as living quarters, as premises for holiday camps and holiday centers" [8, p. 19-20]. Arkhipov was strong in his conviction that restaurants, cafes, banquet and dancing halls, libraries and lounges in museums ultimately lead to the loss of the historical image of Peterhof.

While attempting to resolve the pressing issues, the director failed to find support anywhere. Not willing to yield his principles, he saw this situation as desperate. "I am alone and have decided to ask for resignation upon completing construction in the summer (1937. - E. K.)", he later wrote [8, p.23]. He, however, was forced to leave the director's post against his will: the event in the autumn 1937 followed the scenario usual for this time - slander, defamation by colleagues, accusations of collaboration with people's foes, etc. The director was castigated at meetings and conferences. He was accused of his friendship with Kliuev who had fell out of favor with the authorities, he was blamed for his incorrect ideological management of the museum and for his patronage of the "people's foes".

On June 2, 1937, Shemansky, Arkhipov's deputy for art research, was arrested. Shemansky and Arkhipov had worked together for twelve years, first at Oranienbaum and then at Peterhof. In early October, after a search in his office, the director was charged with setting up a "counter-revolutionary group of saboteurs" and instilling counter-revolutionary Trotskist ideology in the collective. Neither Stalin's visit nor his personal contribution to the preservation of the "Russian Versailles", government awards ${ }^{2}$, high attendance and profitability of the museum saved the director from arrest. Arkhipov was convicted and sentenced to five years of labor in the Perm (Molotov) region at the construction site of the pulp factory in Solikamsk. "I was mistakenly accused of a number of serious crimes, they blemished me, the one who stems from working people, as a 'people's foe' and at the same time they deprived me of the inalienable right of any accused person to defend myself", he wrote later in his appeal [8, p.24].

Arkhipov was to spend years in exile and during this time, his colleagues at Peterhof were witnessing his misfortunes and waiting for his release.

"After the war in 1945, Arkhipov Nikolai Ilich returned from the labor camp. ...At that time, he was not allowed to live in Leningrad and he settled in Novgorod. But Nikolai Belekhov $^{3}$ invited him for council meetings at KGIOP (Committee for the state preservation of historical and cultural monuments $)^{4}$, and he helped with materials from his

${ }^{1}$ Until this day, the Peterhof museum complex is not able to resolve the problems arising from similar erroneous decisions.

${ }^{2}$ In 1934, to celebrate the decade of his work, Arkhipov was awarded a Certificate of Appreciation and a gift-watch from the Leningrad Soviet Presidium.

${ }^{3}$ Belekhov Nikolai Nikolayevich (1904-1956) - architect, restorer, one of the founders of the Leningrad school of restoration, chief architect (1936-1941) and head of KGIOP.

${ }_{4}$ State register for architectural monuments protection was initially set up as a department in Petrograd in November, 1918. 
archive (which was kept by his relatives) such as the necessary photographs and other facts without which we would have had problems", recollected architect Yevgenia Kazanskaya $^{5}[23$, p. 400$]$.

In June 1953, Arkhipov received permission to live in Leningrad, but he did not strive to come back to work at Peterhof. His long solitude and deprivations had changed his character and his plans. Now his knowledge and expertise were once again in demand; he continued his research and helped to restore the Peterhof complex, but he did not want to "wear again the administrative and managerial yoke", as he put it.

Until the end of 1957, he worked for KGIOP, studied many archives and was proud of "disentangling for the mere clarity" the question of the initial steps of the construction at Peterhof. The result of his research was a summarizing book on the history of the park and palace complex of Peterhof, which has not lost any of its relevance [24].

Arkhipov described his director's career as full of challenges, "My 13-year-long career at Peterhof was very demanding and required not only my initiative and effort, but a lengthy and strenuous fight against those who considered the preservation of monuments at the imperial Peterhof incompatible with Socialist construction. I put forward different projects of profitable use for this place. I had to hear many disdainful and ironic remarks, even from officials who looked suspiciously at the 'custodian of the Tsar's wealth' and did not understand that it was all about Russian history and culture..." [8, p.27-8].

Having survived the time of the "Great terror" and his personal drama of repression, Arkhipov as the second director of Peterhof museums and parks remained unfaltering with his life principles. In the capacity as museum director, he managed to raise the museums of Peterhof to a high standard of museum work; he studied the history of construction and life at the former residence. His place in the museum history of Peterhof is exceptional. With his departure, the period of directors-professionals came to a standstill for quite some time. Administering museums was deemed to be ideological work aimed at guiding people's mindsets, so museums were staffed by apparatchiks for many years.

Arkhipov and many other employees of suburban museums were accused of misappropriation of treasures from the imperial palaces, which was the reason for initiating several criminal cases. This resulted in a decision to commence major audits in the museums of Peterhof, Gatchina, Pushkin and Pavlovsk as well as in some museums of Leningrad, which were conducted in the 1938-1940's [25]. At the beginning, there was an identical situation in all suburban complexes, palace treasures had not been rigidly divided into objects of art and utilitarian objects used by the imperial family; there were not any standard accounting documents. Controlling organizations did not write or provide any instructions with regard to recording and storing museum assets. Each museum director had to build a storage system as it suited him.

Heads of suburban museums had permission to sell objects of everyday use from palace storage - artifacts from certain periods, which were often taken abroad against the will of the directors. In the early 1930s, art treasures were sold on a massive scale via the agency Antique in order to gain foreign currency and the disorder that existed in the old inventory records prompted investigative bodies of the NKVD (the People's Commissariat for Internal Affairs) to report thefts in museums. Moreover, directors were forced to spend

${ }^{5}$ Kazanskaya Yevgenia Vladimirovna (1915-1997) - architect, restorer, together with Savkov prepared a project of the restoration of the Grand palace; she headed this reconstruction. 
the money allocated for the restoration of monuments and other purposes on the organization of mass holidays and receptions for senior officials.

An audit of Peterhof's collections ${ }^{6}$ served as a background for a professional career of Pavel Amosovich Konopelko (1902-?) who, on the order of the Department for Cultural and Educational Affairs of the Leningrad City Council of March 16, 1938, took over the post of director at the Peterhof museum-palaces and parks vacated after tragic events. The new administrator arrived in Leningrad from Belarus. He had neither the appropriate education nor the necessary experience. In his personal data file he stated his "social background, profession and occupation" in the following way, "of peasant origin, unskilled laborer, unemployed".

By the moment of his appointment, Konopelko, who was a propagandist of the Party, had taken a course at the Higher School of Trade-Unions and studied at the history department of the Institute of "Red Professors". His management principles were continuously compared to the working principles of Arkhipov who enjoyed great respect among his colleagues; and the comparison was not in favor of the new director. Probably, this was one of the reasons why he volunteered to resign in August 1940 and took another job as a lecturer at the Financial and Economic Institute.

The vacant position was soon offered to Jozef Vladimirovich Finkelstein (19091942) whose education included a trade-union school in the city of Odessa, "rabfak" (workers' school) the Leningrad Financial Institute and two years of law school. From 1933, he was engaged in education work - until August 1934, he headed a team of lecturers at the department of education of the masses at the Leningrad City Council; for the next four years he was director of the Leningrad center for organizing public lectures, and from September 1938 to January 1940 he worked as a deputy director of the Central Park of Culture and Recreation named after Sergei Kirov. In the personal file of Finkelshtein, there is a record of a serious reprimand from the Party seniors, in 1938 the disciplinary punishment was lifted and this did not prevent him from taking a high post. We can assume that his administrative career in the sphere of cultural work played a certain role in his appointment because the city government considered such experience essential for the head of the Peterhof museum. On January 9, 1941, Finkelstein's appointment was confirmed at the meeting of the Executive Committee of the Leningrad City Council of Workers' Deputies chaired by Popkov.

Soon the war began and although Finkelshtein was most likely exempt from recruitment, he volunteered to go to the front. A week later his deputy Shemansky followed him (as early as January 1940, his case was dropped and from September he resumed his work at Peterhof as the director's assistant for museum work). At the hardest moment in the early days of war, the museum was left without people with management experience in museum work. ${ }^{7}$

Then the post of director was taken by Martin Mikhailovich Rebane (1889-1968) who was in charge of the Chinese Palace and the parks at Oranienbaum. Born into a family of workers in the Governorate of Livonia (Republic of Latvia), he rose to the rank of an officer in the tsarist army and then became a political officer of the Red Army. From 1920 to 1940, he repeatedly changed his place of service, held different posts as a Party

6 56,265 items were recorded in inventories at Peterhof in 1938-1939.

7 In January 1942, A. V. Shemansky died on the Leningrad Front and in February, Y. V. Finkelstein died on the Kalinin Front. 
and Soviet official, and having no special education was nevertheless promoted to several positions of importance. In 1922, Rebane moved to Petrograd where he taught at the Department of Soviet Law of the Communist University of National Minorities of the West named after Markhlevsky under the People's Commissariat for Education. Six years later, he moved to Ukraine, where he headed the Pedagogical College in the city of Kamensk. Upon returning to Leningrad in 1932, he served in the Regional Trade-Union Council and in 1933, he became deputy director for scientific and political work at the Gatchina museum-palace and park.

The events of the year 1937 did not spare Rebane as he was purged from the Communist party on a false charge and fired from the museum during the purges of staff. Later he was able to get a job as ice-skating rink builder and a gardener of the Central Park of Culture and Recreation named after the First five-year plan (Tavricheskiy Garden). Two years later, he had his Party membership reinstated, recovered his post at Gatchina Palace and on December 17, 1939, he was appointed director at Oranienbaum museum-palace and park.

As many senior workers left for the front, Peterhof suffered a severe shortage of personnel and on June 29, the decision was made to merge the Oranienbaum and Peterhof museums under a joint directorship, with Rebane assuming responsibility for both palace and park complexes.

Upon receiving a written order to prepare museum collections for evacuation, the employees carried out large-scale work to relocate museum objects to remote storage during July-September 1941. In the shortest time possible it was necessary to make lists of art treasures, obtain permission to evacuate them and find transport and packaging material. Peterhof museums were provided with only eight rail carriages and one open wagon, which proved to be insufficient. Nevertheless, to give credit to the director's efforts and organizational skills, the most important museum objects were packed and preserved: six shipments left for their destinations: three were dispatched to Gorky, two - to Sarapul ${ }^{8}$ and one - to Leningrad.

Moreover, employees of the museum managed not only to send some marble statues to areas which were thought to be less at risk, but also to hide a significant portion of them in the grounds of the parks. Museum workers were aggrieved at the thought of leaving the sculptural group "Samson Tearing the Lion" by Kozlovsky in its historical place. "Samson alone was out of luck. We were not allowed to cut it into pieces. It weighed more than nine tons and we had neither the equipment nor strength to move it", according to Rebone who recalled saving museum valuables in his memoirs written many years after the war $[3$, p.345-6].

"The work was in full swing there. Responsibilities were clearly divided among managers supervising constant teams and groups", he later noted [3, p. 346]. Hard and strenuous work usually done by men fell on women's shoulders. Every evening, the director held operational meetings with all those in his charge.

This laborious period of the museum's evacuation lasted three months. On September 23, 1941, on the eve of the German invasion of Peterhof, Rebane moved to Leningrad where he soon fell ill. In December 1941, he was relieved from the position of director at

8 The second shipment of the museum collection did not make it through the siege to Sarapul and was stored at St. Isaak Cathedral in Leningrad. 
Peterhof and Oranienbaum museum-palaces and was urgently evacuated to the rear of the country.

Rebane was the first director at Peterhof who had had some experience in museum work before he took up this high position and whose career turned out to be probably the most challenging in the whole century. Certainly, full credit must go to the director who managed to rescue about twenty-two percent of the museum's pre-war historical collection, which after the war numbered 12,932 pieces. Being in evacuation, Rebane was able to remember places where park and fountain sculptures were "buried", which facilitated the post-war search for them [3, p. 347-8].

Saving museum property became Rebane's personal contribution to the history of Peterhof. In the post-war years, he lived in Estonia and worked as director of the Ethnographic Museum of the Academy of Sciences of Estonia. In 1967, he made an attempt to establish contact with the museum administration at Peterhof by sending his recollections of the evacuation to the museum, but nothing is known if this resulted in anything.

On January 19, 1944, divisions of the $2^{\text {nd }}$ assault army of the Leningrad front liberated Peterhof which was in ruins. "The Peterhof Palace is destroyed to such an extent that no human efforts will be able to revive it", wrote the poet Olga Bergholz who at the end of January visited Peterhof together with other members of the committee estimating the damage done to the suburbs [16, p.153]. However, only a few months passed, and the museum began a new life. Yakov Ilyich Shurygin (1904-1998) became its director. He was appointed to the post on August 1, 1944, immediately after the Executive Committee of the Leningrad City Soviet adopted a decision to restore and maintain suburban palaces and parks.

Born into a family of peasants, Shurygin arrived in Leningrad in 1931 and as a student of the Pedagogical Institute Herzen he began to conduct tours of the city and explore museums. After graduation, he was sent to work in Kursk where he taught Russian language and literature. In the summer of 1937, he returned to Leningrad and on July 18, started working at the Director's Office of Peterhof palaces and parks as a tour guide. A month later, Shurygin became a researcher and curator of the Lower Park museums and from December 1, he worked there as deputy director for science and museum work, i. e. he took over the post of the arrested Shemansky.

After Shemansky's political rehabilitation and return to the museum, Shurygin took a job at the Central Naval Museum in October 1940. When the war broke out, he went to the Leningrad Front where he was in command of a military unit on the Pulkovo Heights; he was seriously wounded in the head, underwent a long treatment and after returning from evacuation worked for the district military commissariat of the city of Alapaevsk. He was awarded the medal "For the Defense of Leningrad" (1943), "For the Victory over Germany", and the Order of the Red Star (1951).

Immediately after the liberation of Peterhof, he was asked to come from the Urals and in August as an experienced museum worker, he was appointed director of the Peterhof palaces and parks. Now he faced the challenge of restoring the barbarously destroyed complex. During this stressful time, the Director's Office was located in the quarters of the Grand Palace under the emblem of two-headed eagle, and the employees discussed the future of Peterhof almost around — the-clock here. "On long winter nights in 1944-1945, sitting at a table by the iron stove in the ice-cold room, we tried to figure out the damage caused to Peterhof by the German invaders, we always thought that no rubles, stamps, or 
dollars would ever be able to pay for the loss of art treasures. Therefore we need to protect everything that we managed to preserve during the war time", Shurygin recalled [2, p. 10].

Under his management, the hardest and most tedious work was done: the Lower Park was cleared of mines, debris, dugouts, trench shelters and bunkers; anti-tank ditches and trenches were filled in; deadlines and priorities for work were set. It was decided to commence the revival of Peterhof from the fountains, which, in the firm belief of the director, defined its identity and its future. On August 14, 1946, the Executive Committee of the Leningrad City Soviet adopted a decree "On the restoration of fountains and park premises in Petrodvorets" [16, p. 224-5]. City organizations promised to repair part of the water supply system outside the historical complex. Water supply on the territory of the park and the repairs on hydro-systems were in the hands of the Director's Office of the museums and parks at Peterhof.

In the summer of 1945, the park was opened for visitors. Prior to that, it was necessary in the shortest time possible to remove debris from the remote parts of the park, and the director had an idea to take advantage of the prisoners of war camped near the railway station New Peterhof. In response to this request, on the eve of the opening of the Lower Park, the camp warden sent 50 people to work during the day and 150 at night. By the next morning, all the alleys were in order, and a team of carpenters hammered together garbage bins [2, p. 101].

Restoration work continued in stages: on August 25, 1946, the first set of fountains started functioning, which required a large number of new nozzles, without which water jets could not work. In the summer of 1941, when the war began, two thousand spare parts were stored in boxes in the Grand Cascade grotto, but they did not survive. At the end of 1945, the director was looking for a factory to place an important order, but a team of fountain makers from Peterhof volunteered to make such nozzles in their workshop.

Three days before the opening of the fountains, representatives of the Leningrad Regional Party Committee, headed by First Secretary P.S. Popkov arrived in Peterhof. Against the background of the fountains of the Grand Cascade rising high, there was an empty massive pedestal of the Samson statue. The city officials suggested that Shurygin should urgently find a solution, and, as a result, a vase of flowers was placed on the dais, water flows were directed to it and that is how the Grand Cascade met its guests.

On August 31, 1947, a new sculpture of Samson was placed on the historic site, and on September 14, the second set of fountains was formally unveiled. Shurygin repeatedly insisted on the restoration of park facilities of the Meadow and Kolonistsky Parks; he urged city authorities to start work on the conservation and restoration of the Rose Pavilion and other architectural structures on the water conduit, but his pleas were ignored and these monuments are still in ruins today.

Serious debates began on the issue of restoration and future use of the Grand Palace. "It was impossible to realize the amount of damage done to it; it was beyond comprehension that everything that remained in the palace had been destroyed. For example, gilded carvings burned to the smallest detail. Generations of Russian people had taken great care to preserve the palace. I remember how all the decorations were meticulously protected, how museum workers strictly watched visitors so that they did not touch the objects of the interior and the fabrics on the walls. And how they cared for the parquet floors, how they carefully washed and waxed them once a year. Even staff were not allowed to wear street footwear inside the museum before the beginning of the summer season. The palace 
was not heated, that is why it was open only in the summer months. From the thread-bare carpets, museum workers made slippers with soft soles to put on over the street shoes", wrote Shurygin [2, p. 29].

Considering the condition of the complex, at the early stage there were no plans to restore its interiors: the initial plan was to use the palace rooms as a holiday center to hold different mass cultural events and spectacles, to arrange exhibitions, to entertain people with concerts and films, lectures, chess and checkers games, to work with children, to open a restaurant, snack bars, etc. However, common sense prevailed. Belekhov, head of the KGIOP, succeeded in saving the palace at a special meeting dedicated to "the fate of suburban palaces" in Leningrad in 1944, and then at the Council of Ministers of the USSR in Moscow in 1948.

Under Shurygin's leadership, 1946 saw the beginning of restoration work on the cascades The Golden Hill and The Chessboard Hill. The earliest monument to be reconstructed was Peter the Great's palace Monplaisir. "When in August 1944 we were walking form the Chessboard Hill to Monplaisir, - Shurygin recollected, — from afar, it looked damaged but not severely, because the roof was intact. Upon coming closer, it became evident that it was a false impression. After closer inspection, it turned out that the condition of Monplaisir was appalling and much had been lost forever. For long months, everything here had been systematically and consciously destroyed and burnt. German invaders had left a stamp of their hatred for other nations and their culture" [2, p. 39]. Right after German troops were driven out, work began on cleaning the rooms, collecting and documenting fragments of decorations, checking the condition of the building. Arkhipov was engaged in the preparation of scientific and planning documents [26, p. 108].

The career of Shurygin in early 1948 came to an abrupt halt. The materials and audit act regarding financial and economic activity of the Director's Office of parks and palaces at Petrodvorets are evidence of a dramatic twist in his career. According to these documents, the director misappropriated construction materials intended for the construction and restoration of the fountains. Taking into account the complexity and controversies of the time when he lived and worked, we can express some doubts regarding the validity of charges he was accused of. Nevertheless, in April 1948, he was dismissed from director's post and became chief curator.

In January 1951, Shurygin expressed his desire to resign and left Peterhof for the KGIOP where he did not work long. The next thirty years, he was a researcher at the Museum of the History of Religion and Atheism (Kazan Cathedral). In 1965, he defended his $\mathrm{PhD}$ thesis on the art of the sculptor Orlovskiy, and afterwards he authored numerous research papers.

Shurygin occupies a special place in the history of Peterhof for his important role in the very beginning of the post-war restoration of the reserve, of which he recounts in his memoirs. He also recollects the tragic death of the Peterhof "Landing troops" on October 5, 1941 [2, p. 48-50].

On May 6, 1948, Alexey Gerasimovich Demidov was transferred to Peterhof from the Kirovskiy District Soviet of Leningrad where he worked as head of the culture and education department (1906-?). The new director's great experience in organizing public events was a crucial reason for his appointment. The human factor also played its role: Demidov and Shurygin had strained relations; we can suppose that Shurygin's demotion left him unhappy he began to lodge complaints about the state of things at the museum 
to the Executive Committee of the Leningrad City Soviet and Petrodvorets district Party committee. The conflict between the two administrators affected negatively the entire atmosphere in the collective.

The condition of the Grand Palace still remained one of the primary issues for the director. Soon after Demidov's appointment, Act No. 3448 of September 14, 1948 “On restoration of the Grand Palace at Peterhof" was adopted by the Council of Ministers of the USSR. It ordered, "to reconstruct the Grand Palace at Petrodvorets as a historical and architectural monument". It required the preservation of the former appearance of the facades with the exception of the Church Building which was to be one-domed in accordance with Rastrelli's original design. Historical interiors of five rooms of the Grand Palace were to be restored - the Chesme Hall, the Throne Hall, the White Room, the Mirror (Dance) Room and the Formal Merchants Staircase. In 1951, architects Vasiliy Savkov ${ }^{9}$ and Yevgenia Kazanskaya produced the concept and design project of the Grand Palace restoration in accordance with the historical appearance of the palace's interiors.

Cultural work with masses, at which the director had been so good at previously, was not the first priority at Peterhof which was undergoing the process of a complex restoration. An expert in another field was required. At the end of 1949, Demidov was transferred to the position of director of Gatchina Palace, the restoration of which was not even considered at that time. As a result, the director's post at Peterhof became vacant once again.

The next director Nikolai Grigorievich Tikhomirov (1908-?) who had previously been director of the Philharmonic Society in Smolensk, had neither the necessary administrative expertise nor an understanding of the restoration process. However, on December 30,1949, he was sent to Peterhof where he worked for two years. His dismissal was caused by a seemingly trifle reason: the officials, in charge of the city's culture, noticed that the director's wife, the singer O.M. Mukhtarova, gave too many concerts at Peterhof. During his directorship, she took part in 38 out of 41 concerts at the museum.

The wave of changing directors most likely worried city officials. The Chief Office of Culture of the Executive Committee of the Leningrad City Soviet seemed surprisingly reluctant to find a director for Peterhof with a special training in history, art history and architecture; instead, it strictly pursued the policy of filling vacancies with cultural education workers.

Mikhail Stepanovich Pavlov (1892-1951), an experienced party functionary in the sphere of culture who had been director of the Center for cultural activities at Petrodvorets, took over as director at Peterhof on January 26, 1951, but died shortly thereafter.

On January 2, 1952, Alexei Nikolaevich Dometskiy became the new director. A graduate of the Higher School of Trade-Unions, a war veteran awarded with orders and medals, he came to Peterhof after being the head of the culture and education department of the Kirovskiy District Soviet. The beginning of his work coincided with the restoration of the facades of the Grand Palace, which were completed in 1957. The ten-year long directorship of Dometskiy was a time when many monuments were restored: the Hermitage (1952), Monplaisir (1961), The Chessboard Hill (1953) and The Golden Hill (1955), the fountains Conservatory (1956), Favourite, Mezheumny (1957), Little fir (1958) and

${ }^{9}$ Savkov Vasiliy Mitrofanovich (1907-1978), architect and restorer, one of the founders of the Leningrad school of restoration; together with Kazanskaya he worked on the project and headed the reconstruction of the Grand Palace (1949-1974). 
others. From 1956, the Bath building of Monplaisir was under reconstruction. In 1957, the monument to Peter the Great by Antokolsky was placed in the Lower Park. During the war, it was plundered and a new statue was cast in accordance with the author's model.

Though Dometskiy established himself as a demanding administrator respected by his colleagues, one can suggest that the atmosphere at the museum was far from quiet. The chief curator N.N. Fyodorova remembered that Dometskiy "had to leave against his will, because of slander and injustice. ...He was bothered by audits, some financial infringements were revealed, and he was accused of nepotism because the director's wife was the chief accountant of the museum" [27, p. 77].

Documents confirm the fact of repeated financial audits of the Director's Office, and in 1960, the director was reprimanded "for severe infringements in personnel and financial discipline, an absence of financial control and excess spending of state money".

On the 26 of June 1962, after another audit, Dometskiy was dismissed. From July 2, he began working as deputy director of the State Museum of Leningrad History. Considering Fyodorova's evidence, a dismissal for "severe financial infringements" followed by the appointment to a quite responsible post produces a strange impression: a traditional rotation of personnel typical of that time can be suggested. Besides, the documents listing the director's "sins" can suggest that the circumstances requiring certain steps on behalf of Dometskiy in a number of cases could have been "beyond his capacity". In general, the mentioned "slips" of Dometskiy look rather insignificant.

Suffering from serious lung disease, he made up his mind to change the climate and left Peterhof for Dushanbe. From 1963, Dometskiy worked for the Ministry of Culture of Tajikistan and dealt with protecting monuments. Upon returning to Leningrad in 1965, he took up work at the State Museum of Leningrad History and headed the museum complex of "The Fortress at Shlisselburg". In 1970, he began to work for a newly established research and restoration workshop at the Chief Office of Culture. In 1972, he tragically died and was buried at Babigon cemetery in Peterhof.

After Dometskiy's dismissal, Anatoliy Alexandrovich Grigoriev (1916-?) was appointed director in 1962. He used to be an actor and director of the club "Krasnoznamenets". Under his command, a long-awaited event took place - the first rooms of the Grand Palace with restored interiors opened in May 1964: The Portrait Hall, The Divan Room, The Partridge Reception Room and The Crown Room. An exhibition was opened in the palace devoted to the history of the Peterhof complex, its birth, destruction during the war and post-war reconstruction. The desire of visitors to get into the Palace was so great (their number exceeded pre-estimated figures by four times!) that the management of the museum failed to organize expedient tours of the formal rooms. Numerous negative commentary followed, which probably led to Grigoriev's dismissal and his transfer to another job at the club of "Bolshevichka" factory.

In 1964 for the first time in Peterhof history, a woman became the museum's director. Yevgenia Ionovna Korchagina (1919-?) was raised in a working family and studied at the Institute of Chemistry and Technology named after the Leningrad Soviet, though she did not finish it. During the siege of Leningrad, she served in the anti-aircraft defense forces and kept vigilance on the roofs of houses during air raids putting out firebombs. After the war, she received additional training at the Higher School of Trade-Unions named after N. M. Shvernik. In 1965, Korchagina employed Znamenov to work at Peterhof and warned him about the hardships of museum work. The latter recalled, "She was not a Party 
member, but took an active part in Party activities... She attended Party meetings and had great experience in museum work, too. She worked at the Summer Palace in the Summer Gardens and benefitted from this work. She knew St. Petersburg's museums well” [IV].

Korchagina, like other "Soviet" directors, did not enjoy the respect of the museum staff. They considered her an undereducated person and, according to some witnesses, often made fun of her. Yet, she worked at the museum for four years, longer than many of her other predecessors. Peterhof began to welcome guests of honor, its director was supposed to behave in a different way - to wear a business suit, be self-confident, be able to tell the history of the palace, and to speak foreign languages. "I am not aware of the actual reason for her dismissal, but the district Party officials strongly recommended her to leave voluntarily because of squabble and rumors which divided the collective and which Yevgenia Ionovna failed to cope with", her successor Vasiliy Konyukhov remembered [V] ${ }^{10}$.

Vasiliy Ivanovich Konyukhov (1930-2013) started his career at the Leningrad electromechanical plant that produced typewriters. His political career began in 1963 when he took the post of instructor of the organization department in the Petrodvorets district Party committee. The committee paid special attention to the museum-palace complex, as he recalled. Some important party leader once said that, "without such a famous museum-palace complex that is being restored by direct orders from the government, there would never be a Party committee in this district". This emphasizes how significant the complex was!" [V].

In 1965, Konyukhov took a correspondence course at the Higher School of Party Work at the Communist Party Central Committee in Moscow, and in 1969, he received his diploma of higher education. Forty years later, he wrote about his appointment at the museum mentioning that after Korchagina's dismissal, "neither the Central Office nor district Party committee were able to find the right person to fill the position. Zoya Alexandrovna Novikova, then a leader of the Party district organization, offered me the post. She spent a while trying to persuade me to accept it. I realized that this high position required 'our own' person and at the same time, I hesitated, as I had no education in history or art history. Finally, I was compelled to agree: the Party ordered and I obeyed. I was dispatched to work as director of museum-palaces and parks at Petrodvorets on the decree of Petrodvorets district Party committee of November 15, 1968. The order of my appointment was signed by Arnold Vitol, head of the Department for Culture of the Executive Committee of the Leningrad City Soviet" [V] ${ }^{11}$.

From the very first days, the director set before himself a task of carefully examining the condition of all Peterhof property. "I wanted to get a general idea of how much work had been completed before my appointment as director and how much of the museum's property was yet to be restored, - Konyukhov remembered, - First of all, our concern was the fountains of the Lower and Upper Parks. We realized very well that people coming to Petrodvorets were eager to stroll in the parks and admire the fountains. At that time, 147 fountains were functioning" [V].

He discussed the prospects for Peterhof together with Savkov and Kazanskaya, meticulously studied the surviving black and white photographs of interiors, which were later

${ }^{10}$ Courtesy of the author's daughter Konyukhova E. V.

11 Vitol Arnold Yanovich (1922-2000), scriptwriter, journalist, honored worker of culture of the RSFSR. From 1962 he was head of department of culture at the Executive Committee of the Leningrad City Soviet. 
used to make drawings and templates in accordance with the original interior designs. The restoration of the Throne Hall and the Chesme Hall (1969) was soon completed; the Chinese Study (1971-1972) and the Blue Reception Room (1975) were also restored.

Konyukhov viewed his primary task as establishing contacts with his colleagues: all his predecessors talked about tense relations among the employees at Peterhof. He managed to assemble a group of professionals who skillfully served the cause. Among the director's close assistants and like-minded people there were I. M. Gurevich, deputy director for science; I. I.Savushkin, deputy director for general issues; V.P. Osadchiy, deputy director for cultural work with masses; V. V.Znamenov, chief curator; B. V.Lobovikov, chief engineer; K. K.Zabelina, head of park and garden department; L. S. Romanovich, head of guide and tour department; and researchers G. N. Goldovskiy, E. G. Myasoedova, V. M. Tenikhina, M. I. Obaturova, N. V. Vernova, V. I. Korshunova.

"It was my duty to have them fulfill particular assigned work, especially that of the restoration of palace interiors. We had to solve urgent problems every day and included them in the agenda at meetings of department heads and middle level managers making appropriate decisions. The Chief Office of Culture, a unit of which we were, approved our yearly financial scheme and we had to adhere to it strictly. We took all the necessary measures to do that. Departments as well as suburban complexes were involved in the Socialist emulation", the director wrote [V].

Before the summer season of 1969 , major repairs on the main fountain water supply conduit were completed. New cast-iron pipe barrels were laid along the way, this important work being done by Peterhof fountain makers. The position of a fountain foreman was always considered to be the most important one and directors sought to get on well with the team of fountain makers. "The position of a fountain foreman is a key because fountains are the most important elements of our palace complex, its pride and beauty; they are silver jingling and singing jets which symbolize the symphony of fountains", Konyukhov recalled [V].

Now the museum workers were faced with the task of accommodating exhibits in the restored palace as many historical objects were destroyed or lost during the war. It was time to find copies and replicas in order to replace them. However, the budget did not have any money for the acquisition of museum objects.

Another important task was the organization of cultural events for the masses, public holidays, light and music shows, fireworks, ballet performances and weekend entertainment in order to attract visitors. The central part of the Grand Cascade, surrounded by illuminated fountains and adjoining alleys of the park, served as the main backdrop. Many "Peterhof festivities" were ideologically loaded, which can be seen in their names: "The road of glorious work", "Remembrance torch", "The rest day of Leningrad builders" and others. Following the tradition, each of these ended with a colorful display of fireworks. In 1973, the museum celebrated the $250^{\text {th }}$ anniversary of Peterhof fountains.

On September 1, 1977, Vadim Valentinovich Znamenov (born in 1936) was appointed director. By that time, he had worked as chief curator at the museum for twelve years. Contrary to his predecessors, he had professional training - he was the first out of fourteen directors to have graduated from the history department of Leningrad State University named after Zhdanov and, as he knew the city history quite well, he had worked as a tour guide for many years.

"I worked honestly and never thought of the director's post, - Znamenov said later, - Besides, I still believe that it would have been more beneficial if I had worked as 
chief curator at Peterhof. In Russia it works this way. If you want to succeed, you must be a director. In this case, you will attain certain independence in making decisions, you will be able to define a problem and solve it. You need to just fit in a legal framework and that's it" $[12$, p. 180].

Each period of the director's work witnessed increasing and expanding restoration work in the Grand Palace where new rooms opened one after another: The Blue Room and The Oak Staircase (1978), the Audience Hall (1979), the Merchants Staircase (1985), the Dance (Merchants) Room (1995), The Church of the Grand Palace (2011). New venues were opened: the Cottage at the very end of 1978 after its long reconstruction, Marli in 1982, Catherine's Building of Monplaisir in 1986, the Bath and the Assembly Hall of Monplaisir in 1997 and the Gothic Chapel in 2006.

Visitors at Peterhof could not help admiring the new fountains in the Lower Park with the restored fountains added year after year: The Golden Hill, Cloche, Menagerie (1980), The Lion Cascade (2000). In 1989-1995, major restoration work on the Grand Cascade was completed.

In 1983, the museum complex received its new name "The State Palace and Park Museum-Reserve in Petrodvorets". The title common for all European natural parks reflected an unfolding transformation of Peterhof landscapes. "The status of the museum-reserve... carries more and more weight, - a local newspaper 'Zarya Kommunizma' said, - To make sure, just visit some detached plots of the Lower Park, especially in its western part. Constructions representing the so-called small forms, alien to the reserve featuring landscape architecture of the $18^{\text {th }}$ century are being removed from there. An ice-cream storage and a cafe have already been demolished near The Black Slope. The snack bar and adjacent buildings located on the children's playground have been knocked down. Those ugly structures distorted the design, disrupted the composition of the park and the original concept of the complex" [11, p. 170]. Ideologically loaded culture was ousted from historical parks.

In 1990, the Peterhof Museum-Reserve together with other Petersburg suburbs was included into the list of UNESCO World Heritage objects. Its property expanded with the addition of the Chevalier Palace, Ministerial and Maids-of-Honor Houses. Alongside with the restoration of interior museums, it became possible to open museums of a new type - those which were culturally and historically connected with the remarkable cultural phenomena of St. Petersburg: the Benois Family Museum (1988), the Museum of Art Collectors (2002), the House of Playing Cards (2007). The wooden palace of Peter the Great in Strelna, the oldest building of the entire Museum-Reserve, supplemented the architectural complex. In 2006, the palace and park complex of Oranienbaum was incorporated into the Peterhof complex. A comprehensive restoration of the Farm Palace began in the park of Alexandria.

The period of rapid growth of the Peterhof collections is mainly associated with Vadim Znamenov, a connoisseur of artistic objects and a museum collector. In order to open new exhibitions, numerous elements of home décor were needed and as he said, he was "able to find and purchase many things. About three hundred new objects were acquired for the collection every year. "Not a day without a line" - that's how we jokingly defined our motto, because on receiving every object we enter a separate line for it in the 'Register"' [11, p. 181]. With the fourteenth director, the Museum-Reserve, proud of its history, 
marked two notable dates - 300 years of St. Petersburg (2003) and 300 years of Peterhof (2005).

Rarely did Peterhof's directors leave any evidence of their professional calling or evaluate their role in the museum's history. In the magazine History of St. Petersburg, Znamenov shared his views on what human and professional qualities a museum leader should have. "He must be a person who treats history as a history of his own life. He also must be a person tinted with romanticism. The history of a Place must be loved or hated (hatred is one of the facets of love), but one cannot be indifferent to it. If these qualities are present, this person has the chance of becoming a nice museum worker and museum leader" [28, p. 6].

To understand the activities of the fourteen Peterhof directors turned out to be not an easy task. In our analysis, we tried to rely on documents, memoirs and oral evidence; however, the sources describing official facts quite often contradict everyday facts, which play an important role in people's life.

The analysis of the fourteen biographies resulted in a number of general conclusions: the majority of Peterhof directors held office for two or three years and one can state with certainty that this time is rather short for a museum leader to understand the specifics of their work. Only three of them held their director posts for more than ten years - Arkhipov (13 years), Dometskiy (10 years), Znamenov (31 years) and the achievements of the museum in the first years of their work are evident.

All the directors had a different education, but only one Znamenov had special training. Few of them, Rebane, Shurygin and Znamenov, by the moment of taking over as directors had some previous experience with museum work. Most directors were Party bureaucrats with varying experience in administrative work. Heading a museum was considered to be cultural work with the masses, and experience of this kind was deemed to be the main criterion for the appointment to a post as Peterhof museum director. This extremely shortsighted view was at the base of many problems which hindered the museum's development.

The merits of the leading Peterhof directors in many respects were determined by the tasks set forth before them by the time. Arkhipov succeeded in greatly preserving the historical image of the parks and palaces. Rebane evacuated the most precious part of the collection at the beginning of the war. Shurygin was in charge of the post-war restoration and opened parks and fountains for the visitors. Dometskiy continued in Shurygin's wake opening the first restored palaces and pavilions. Konyukhov gathered the first team of professionals, and Znamenov was particularly successful in acquiring objects for the collection and opening principally new exhibitions.

After cultural and historical analysis of their work, we can state with certainty that each of them was a person born and brought up by their time, and the time left an imprint on their personalities, their thoughts and motifs behind their decisions. And this was an unalterable process. However, making an attempt to paint their "portraits against the background of time" allows us to take a fresh look at the hundred-year long history of Peterhof.

Serious changes took place during the last decades in the museum life of Russia and St. Petersburg. Their social role became more important, accessibility of museums became a priority, and museum attendance has sharply increased. As before, museums are repositories of treasures, they collect, study and display cultural objects, but the society at present sets before them other important tasks. Museum communities have learned to 
live under the market economy. Long-term planning of their activities, in many respects, determines St. Petersburg's development, which associates museum life with the increasing number of tourists.

Museum directors of today have special training, quite often, they have degrees and they know foreign languages. As a rule, they are engaged in the academic process: they are permanently invited to teach at universities. Very often, they participate in discussions with politicians, businessmen, lawyers, economists and the like.

In the last decade, museum directors have become special managers of culture. In the market economy, their functions and duties underwent changes. It has always been essential for a director to be able to evaluate a situation and make a decision. The analysis conducted shows that the directors had to take risks, adhere to their principles and beliefs, trying not to fear making mistakes and to admit them when they did occur.

The director has always been in charge of the economic policy of the museum. Together with financial departments, they define the financial policy of the institution. Today this policy has drastically changed as the museum can place tender offers and select contractors to do various kinds of work, which at times makes things more complicated for the administration. State funded museums are given the right to take full control of the money earned and received from other sources. The museum began practicing internal audits.

Recently the museum has started to receive financial support from the "Friends of Peterhof", a charity organization at the Peterhof State Museum-Reserve whose members are foreign and Russian companies, charity foundations and individuals whose donations promote the museum's development. Their donations help to carry out different projects, restore the collection, publish books, and organize exhibitions and different traditional festivals. The museum pays special attention to its benefactors inviting them to the openings of exhibitions, special events and festivals. Every year the museum organizes a Birthday of its Patrons' Society. Close contacts with members of society is one of the most important functions for the director. Their personal participation in the events, attracting benefactors, invariably provides good results.

Restoration work at Peterhof has its peculiarities. While the post-war reconstruction was an ideological project, whose success was confirmed by the time, the present day situation with the ruined monuments is more difficult to resolve. Modern day research proves the need of reconsidering a number of clauses of the Venetian Charter: nowadays with the museum director's involvement, a new innovative project of restoring the Lower Cottage has been launched. The Cottage was demolished in the 1960's, but after restoration its historical fragments will blend with the new ones manufactured from materials different from the original.

The museum directors are at the head of economic and administrative activities, they are engaged in scientific work, contribute to culture by writing books, conduct research, and organize exhibitions, which broaden the field of scholarly knowledge. Though museums are officially not scientific institutions, and the post of a "researcher" is replaced by that of a "specialist", young employees express interest in working in archives, they study the museum's history, come up with new attributions for museum art objects and are busy with publications. In this respect, revisiting and rethinking the museum's history throughout the $20^{\text {th }}$ century, timed with the centenary of this imperial residence-museum has become a breakthrough. 
For a long time, museums existed in the atmosphere of militant atheism. At present, the situation has changed and the museum's director has to conduct a dialogue with Russian orthodoxy, to look for a liaison between the religious and secular mindset. We should agree with Mikhail Piotrovsky that culture and religion do not oppose each other; on the contrary, "they supplement each other, though they speak different languages. Moreover, in a time of trouble, they can replace each other. When there was no church in this country, information about religion was passed through museums" [29, p. 104].

Representatives of the religious and secular community have differing views on the most important modern day problems and they evaluate cultural events differently. They, however, understand the need of restoring the monuments of religious architecture and the possibility of displaying museum collections in them. If approached rationally, the question of worship in religious quarters of the museum can be resolved with a sensible compromise. Once a year, on the day of consecration, a service is held for museum employees in three restored and consecrated churches at Peterhof - in St. Alexander Nevsky Church (Gothic Chapel) in Alexandria, in the Court church of the Grand Palace - the Church of St. Peter and Paul, and in the Grand Palace (Menshikov) church in Oranienbaum - the Church of St. Panteleimon).

Exhibition activity in the modern world has acquired quite a new quality, though in landscape museums the attention to exhibitions is not great. Visitors come here, first of all, to see the fountains and to stroll in the parks. The museum is successfully developing outreach programs. For the last decade the exhibitions from Peterhof collection were organized in many Russian cities - in Moscow, Tambov, Lipetsk, Pskov, Petrozavodsk, Pen$\mathrm{za}$ and others. A new type of billboard exhibitions in the park alleys has been suggested where they tell about different events in the history of Peterhof. The Museum-Reserve has acquired a new experience of organizing exhibitions in Italy, Germany, Slovakia, China, etc. The first branch of the museum of a federal status was opened in another region and exhibitions from Peterhof are held in the Aseev mansion in Tambov.

The museum is constantly replenishing its collection, with the director being chairman of the purchasing committee. Directors should understand better than anybody else that a museum is not just a repository of antiques. Directors should not buy or accept as gifts those objects that are of no particular interest to the existing collection. While enriching it, the museum pursues the purpose of acquiring new objects for its historical collection of art works and the collection of objects illustrating life of the imperial household.

PR activities are on the rise in the museum. In the last decade, the practice has been established of publishing museum annual reports, which are certainly of interest for the present and the future and are publications of a new independent type. Traditional interaction with the media acquires new norms, which allow new forms of museum work to be presented to the public. The museum is actively engaging in social networks. A special "face" of the museum is its Internet site, from which the director constantly addresses a million-wide audience.

The museum actively uses designer methods, theatrical performances on the premises of the museum with the use of information technologies; the museum is constantly searching for unusual ways of displaying its collection. In fact, the use of plasma screen TVs with prerecorded historical and reference information is another "method of supplementary exhibitions" of the $21^{\text {st }}$ century, which by no means disrupts the wholeness of the historical space. Exhibitions of recent years, such as "Entertainments at Court", "Summer 
Residents at Peterhof, Oranienbaum through Ages", "The World of Playing Cards" were quite costly and it was the museum's director who took responsibility for their organization considering cost-efficiency and the growing attendance of the museum.

Work with children has also changed. The new education program "The New Farm" was conceived as a set of traditional classrooms, creative workshops, playgrounds and multimedia exhibitions. As an educational center at the museum, the center for children is void of any didactic instruction known in the past as "propaganda and agitation"; the work of this center aims at disclosing the creative potential of the young generation, it helps them to get the general idea of all types of museum professions, including that of a museum director.

In the footsteps of historical festivals, the museum organizes them using modern technologies - a fusion of mapping, light, sound, and other multimedia techniques, with an unchanged part of all Peterhof amusements - large scale fireworks. Organizing performances on the Grand Cascade, the director can perform not only administrative but also a creative function.

In recent years, museum attendance has sharply increased. At this stage, the museum's publicity is in conflict with its repository function, and this process will aggravate. Considering the priority of the latter, the director has to organize the system of admissions with a strict system of logistics as well as a system of museum security.

The museum today develops its own management offering its visitors a variety of services: restaurants, cafes, souvenir shops, concerts in museum rooms and many other things. The museum organizes working places and sources of income around it - shops, hotels, and transportation.

For decades, the museum at Peterhof has been a dominant urban "enterprise" in the Petrodvorets district of St. Petersburg. The fact that people living here work near their homes heightens their responsibility and makes them feel more interested in their jobs because Peterhof is their "small Fatherland".

Today museums are members of the organization "The Union of Russian Museums" - an association of legal entities founded in 2001. It numbers over four hundred museums from 75 regions of the country, which now participate in "The strategy of development of museum activities in the Russian Federation for the period until 2030", which determines the goals, principles, main guidelines and tasks in the sphere of state support of the museums in the Russian Federation.

The museum is a living and constantly changing body. The notion of it as a quiet place of work for specifically prepared people is a notion of the past. Today the museum plays a very important role in social life of the public, and the director is in close contact with the community. It would be a mistake to say that to be the museum director is a vocation: there are few who strive for this work because they consider it not particularly creative. However, if a person agrees to take this job, they become involved in a unique profession, which gives them a chance to experience the happiness of victories as well as the bitterness of losses. This is why the title of this article, in my opinion, is subject to debate. Every museum director used to solve, solves and will solve the issues encountered as director differently.

The analysis of historical experience and modern day situation necessary for understanding the criteria of evaluating the museum director as a successful manager, illustrates that first of all their personal resources should be assessed which are often more important than museum attendance, exhibition projects, financial success and many other factors. 
It is profound knowledge, communicative and partnership qualities and, most of all, the creative potential of the director that determines their success in a modern museum community.

\section{Acknowledgements}

The author is grateful to her colleagues P. V.Petrov and A. S. Belousov who assisted her with the work.

Special thanks to E. V. Konyukhova for providing the manuscript of the memoirs of her father, V. I. Konyukhov.

\section{References}

1. Tikhomirova, Marina. Monuments. People. Events. From the Notes of a Museum Worker. $2^{\text {nd }}$ ed. Leningrad: Khudozhnik RSFSR Publ., 1984. (In Russian)

2. Shurygin, Iakov. Peterhof. Chronicle of Restoration. St. Petersburg: Abris Publ., 2000. (In Russian)

3. Rebane, Martin. "Some Memories of how the Values of Peterhof were Saved in 1941". In Dvortsy i voina. K 100-letiiu nachala Pervoi mirovoi voiny: sbornik statei po materialam nauchno-prakticheskoi konferentsii GMZ “Petergof”, 2014, ed. by Ol'ga Kappol', 342-350. St. Petersburg: Evropeiskii dom Publ., 2015. (In Russian)

4. Vasil'ev, Boris, and Vladimir Potapenko. Academician of Architecture Fedor Gustavovich Berenstam: Materials for a Biography. St. Petersburg: Filateliia Publ., 2010. (In Russian)

5. Chapkina, Sof'ia. "Fedor Gustavovich Burenstam - The First Curator of the Peterhof Palace-Museum”. Russkoe iskusstvo, no. 1 (2011): 83-7. (In Russian)

6. Petrov, Pavel, and Tat'iana Iakovleva. "I did not Feel Justified to Give up my Service to Art and Science". Mir muzeia, no. 11 (2017): 16-20. (In Russian)

7. Kal'nitskaia, Elena. "Making of the Palaces of Museums: Yesterday, Today, Tomorrow". In Ot dvortsa k muzeiu: sbornik statei po materialam nauchno-prakticheskoi konferentsii GMZ "Petergof", 2012, ed. by Ol'ga Kappol', 7-20. St. Petersburg: Evropeiskii dom Publ., 2013. (In Russian)

8. Arkhipov, Nikolai. Research on the History of Peterhof: A Collection of Scientific Papers. St. Petersburg: GMZ “Petergof” Publ., 2016. (Petergofskaia letopis'). (In Russian)

9. Petrov, Pavel. "Martin M. Rebane: The Fate of a Museum Figure”. In Muzei i voina: sud'ba liudei, kollektsii, zdanii: sbornik dokladov vserossiiskoi nauchno-prakticheskoi konferentsii, priurochennoi k 80-letiiu Ekaterinburgskogo muzeia izobrazitel'nykh iskusstv i 75-letiiu evakuatsii kollektsii Gosudarstvennogo Ermitazha na Ural. 4-6 aprelia 2016 g., ed. by Zoia Taiurova, 188-191. Ekaterinburg: OOO "PP 'Artikul"' Publ., 2016. (In Russian)

10. Pompeev, Iurii. Peterhof. History of the Museum. St. Petersburg; Petergof: Abris Publ., 2005. (In Russian)

11. Pompeev, Iurii. “The Creators of Peterhof”. Neva, no. 9 (2005): 158-82. (In Russian)

12. Kal'nitskaia, Elena. "The Age of Pioneers". In Vek restavratsii prigorodnykh dvortsov. Tragediia i triumf. K 100-letiiu muzeinoi zhizni byvshikh tsarskikh rezidentsii: sbornik statei po materialam nauchno-prakticheskoi konferentsii GMZ "Petergof", 2018, science ed. by Pavel Petrov, general ed. by Aleksandr Belousov, 20-37. St. Petersburg: GMZ “Petergof” Publ., 2019. (Problemy sokhraneniia kul'turnogo naslediia. XXI vek, IX). (In Russian)

13. Belousov, Aleksandr. "Is the Director's Chair Soft? Heads of Peterhof Palaces-Museums and Parks in the $20^{\text {th }}$ century". In Gosudarstvennyi muzei-zapovednik “Tsarskoe Selo". Dvortsy, osobniaki, usad'by. Muzeinyi format. Materialy XXIV Tsarskosel'skoi nauchnoi konferentsii, 67-80. St. Petersburg: Serebrianyi vek Publ., 2018. (In Russian)

14. Benua, Aleksandr. "Palace-Museums". In Aleksandr Benua razmyshliaet... Stat'i, pis'ma, vyskazyvaniia, foreword, prepared and comment. by Il'ia Zil'bershtein and Aleksei Savinov, 71-83. Moscow: Sovetskii khudozhnik Publ., 1968. (In Russian)

15. Benua, Aleksandr. Diary, 1918-1924. $3^{\text {rd }}$ ed. Moscow: Zakharov Publ., 2016. (In Russian)

16. "Petergof", gosudarstvennyi muzei-zapovednik (Sankt-Peterburg). Peterhof. Century of the Museum: To the $100^{\text {th }}$ Anniversary of the Peterhof Museum, project manager Elena Kal'nitskaia. St. Petersburg: GMZ "Petergof” Publ., 2018. (Vek muzeev). (In Russian) 
17. Platonova, Natal'ia. “The First Steps in Protecting Monuments of Revolutionary Petrograd (To the Publication of Documents from P. P. Pokryshkin's Personal Archive)". Rossiiskii Arkheologicheskii ezhegodnik, no. 4 (2014), 480-98. (In Russian)

18. Lukomskii, Georgii. The Artist and the Revolution, 1917-1922. Berlin: E. A. Gutnov Publ., 1923. (In Russian)

19. Raskin, Abram, and Tat'iana Uvarova. "Return of the Name: Nikolai Ilyich Arkhipov". Pskov, no. 33 (2010): 129-43. (In Russian)

20. Kal'nitskaia, Elena. "Unknown Episode from the Life of the Grand Palace in Peterhof". In Dvortsy i sobytiia. K 300-letiiu Bol'shogo Petergofskogo dvortsa: sbornik statei po materialam nauchno-prakticheskoi konferentsii GMZ "Petergof”, 2015, ed. by Ol'ga Kappol', 68-75. St. Petersburg: GMZ “Petergof” Publ., 2016. (Problemy sokhraneniia kul'turnogo naslediia. XXI vek, VI). (In Russian)

21. Bondarev, Sergei. "Museum Activity in the Great Peterhof Palace in 1926-1941: Traditions and Innovation". In Dvortsy i sobytiia. K 300-letiiu Bol'shogo Petergofskogo dvortsa: sbornik statei po materialam nauchno-prakticheskoi konferentsii GMZ "Petergof", 2015, ed. by Ol'ga Kappol', 31-5. St. Petersburg: GMZ "Petergof” Publ., 2016. (Problemy sokhraneniia kul'turnogo naslediia. XXI vek, VI). (In Russian)

22. Luppol, Ivan. Dialectical Materialism and the Construction of the Museum. Report at the First All-Russian Museum Congress on December 1, 1930. Moscow; Leningrad: Nar. kom. pros. RSFSR. Sektor nauki Publ.; Ogiz Publ., 1931. (In Russian)

23. Kazanskaia, Evgeniia. "Memories of the Restoration of the Grand Peterhof Palace". In Vek restavratsii prigorodnykh dvortsov. Tragediia i triumf. K 100-letiiu muzeinoi zhizni byvshikh tsarskikh rezidentsii: sbornik statei po materialam nauchno-prakticheskoi konferentsii GMZ "Petergof", 2018, science ed. by Pavel Petrov, general ed. by Aleksandr Belousov, 392-409. St. Petersburg: GMZ “Petergof” Publ., 2019. (Problemy sokhraneniia kul'turnogo naslediia. XXI vek, IX). (In Russian)

24. Arkhipov, Nikolai, and Abram Raskin. Petrodvorets. Moscow: Iskusstvo Publ., 1961. (In Russian)

25. Petrov, Pavel. "General Inventory of Museum Valuables in Peterhof Palaces-Museums from 19381940”. In Gosudarstvennyi muzei-zapovednik “Tsarskoe Selo". Dvortsy, osobniaki, usad'by. Muzeinyi format. Materialy XXIV Tsarskosel'skoi nauchnoi konferentsii, 464-80. St. Petersburg: Serebrianyi vek Publ., 2018. (In Russian)

26. Gessen, Aleksandr, and Marina Tikhomirova. "Restoration of the Monplaisir Palace in Petrodvorets". In Nauchno-issledovatel'skii institut teorii, istorii i perspektivnykh problem sovetskoi arkhitektury. Teoriia i praktika restavratsionnykh rabot, 99-108. Moscow: Stroiizdat Publ., 1972, comp. 3. (In Russian)

27. Fedorova, Nonna. In the Alleys of Memory. St. Petersburg, 2011. (In Russian)

28. "You Have to Live Long in Russia. Interview with the President of the State Museum-Reserve 'Peterhof' Vadim Valentinovich Znamenov". Istoriia Peterburga, no. 1/53 (2010): 5-6. (In Russian)

29. Piotrovskii, Mikhail. There is no Taboo for Museums: 50 Articles in 10 Years. St. Petersburg: Arka Publ., 2016. (In Russian)

\section{Sources}

I. The Charter of the Federal State Budgetary Institution of Culture "State Museum-Reserve' Peterhof"'. Manuscript. Moscow, 2011. (In Russian)

II. TsGALI. F.36. D. 14. [Central State Archive of Literature and Art of Saint Petersburg. Stock 36. Dossier 14] (In Russian)

III. Arkhiv GMZ "Petergof". D-369 [Archive of the Peterhof State Museum-Reserve. Dossier 369]. (In Russian)

IV. Belousov, Aleksandr. From Stories by V. V.Znamenov. Manuscript. 2018. (In Russian)

V. Koniukhov, Vasilii. Autobiography. Manuscript. 2016. (In Russian)

Received: August 10, 2019

Accepted: February 28, 2020

Author's information:

Elena Ya. Kalnitskaya _ Dr. Habil.; ekalnitskaya@mail.ru 